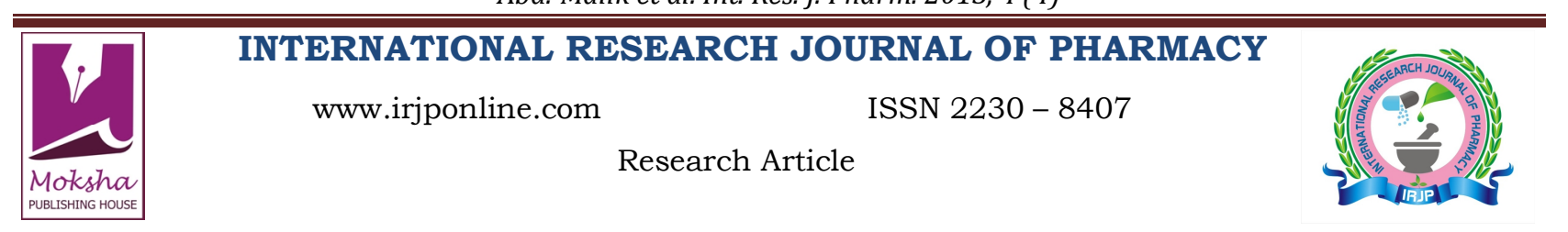

\title{
ANTIDIARRHEAL ACTIVITY OF ETANOLIC EXTRACT OF BAY LEAVES (SYZYGIUM POLYANTHUM [WIGHT.] WALP.)
}

\author{
Abd. Malik, Aktsar Roskiana Ahmad \\ Department of Pharmacognosy-Phytochemistry, Faculty of Pharmacy, Universitas Muslim Indonesia, Makassar-Indonesia \\ Email: malikumi@yahoo.com
}

Article Received on: 18/02/13 Revised on: 01/03/13 Approved for publication: 12/04/13

DOI: $10.7897 / 2230-8407.04418$

IRJP is an official publication of Moksha Publishing House. Website: www.mokshaph.com

(C) All rights reserved.

\section{ABSTRACT}

Indonesia people have been used of Bay Leaves (S. polyanthum [Wight.] Walp.) to treat of antidiarrhea, cholesterol, hypertension, gastritis, and diabetes mellitus. Extrac of Bay Leaves can be inhibit growth of Escherichia coli, Vibrio Cholera, and Salmonella sp. It's the bacterium that produce an entherotoxin so as to cause diarrhoea. Bioassay of antidiarrheal activity by using transit intestinal method and mice (Mus musculus) as an animal model induced by castor oil. The mice were grouped into five groups. Group I is received Na-CMC as control, group II, III, and IV are received of Ethanolic Extract of Bay Leaves (EEBL) with concentration $10 \%, 20 \%$, and $30 \%$, respectively and group $\mathrm{V}$ as positive control by received Loperamide-HCl. The charcoal used to marker as indicators. The result of the test indicate that EEBL have antidiarrheal activity to animal model. Refers to analysis of variant $\mathrm{p}=0.05$, showing that concentration $30 \%$ has an activity non significant with loperamide- $\mathrm{HCl}$ as positive control.

Keyword: Antidiarrheal, Bay leaves, S. polyanthum [Wight.] Walp.

\section{INTRODUCTION}

Diarrhea is one of the main problems in the case of child mortality to $19 \%$ and responsible for the deaths of children under five in developing countries ${ }^{1}$ such as Indonesia. Refers to WHO estimation for the year 1998, there were about 7.1 million deaths due to diarrhea. Diarrhea is a symptom of clinical and gastrointestinal disorders characterized by increased frequency of defecation, usually accompanied by changes in the shape and consistency ${ }^{2,3}$.

Diarrhea is the most given dangerous symptom specially to children. Research to find active extracts antidiarrheal essential to achieving the treatment of diarrhea ${ }^{4}$. Treating diarrhea using medicinal plant extracts have been widely used empirically ${ }^{5}$. Bay Leaves (S. polyanthum [wight.] Walp.) is one of the medicinal plant and believed efficacious for treating of diarrhea ${ }^{5,6}$. Local name is Daun Salam.

Based on the description, to prove the antidiarrheal activity of ethanolic extract of bay leaves (EEBL) should be research in vivo preclinical studies. The results of this preclinical study is expected to be a reference to scientific evidence and material development EEBL as antidiarrheal medication.

\section{MATERIALS AND METHOD}

Material: Mice as animal model (150-200 g) were purchase from Pharmakology Laboratory, Faculty of Pharmacy UMI, Bay Leaves (S. polyanthum [wight.] Walp.), aquabidestilled (Ikhapharmindo Putramas, Jakarta), ethanol 70\%, Loperamide- $\mathrm{HCl}$, Na-CMC, Arabic gum suspension 20\% and tinged with $5 \%$ carchoal as a marker. vortex (CAT.M. Zippear Gmbh. Etzenbach, W. Germany), castor oil.

\section{Preparation and determine sample test}

Sample of Bay leaves was collected from Manyampa Village, District of Ujung Loe, Bulukumba Regency, Indonesia. It was determined by Mrs Aktsar Roskiana Ahmad in Botany Division, Pharmacognosy and Phitochemistry Laboratory Faculty of Pharmacy Universitas Muslim Indonesia Makassar Indonesia. The Bay Leaves is dryed, grinded, and Then powdered to making light of extraction process ${ }^{7}$.

\section{Extraction}

Extraction using modified method from Fang ${ }^{8}$. Bay leaves of $500 \mathrm{~g}$ extracted by macertion method using ethanol solution $70 \%$ and allowed to stand for 5 days, then remaceration to obtain more extract. The Liquid extract are collected and evaporated with rotary vacuum evaporator (rotavapor IKA ${ }^{\circledR}$ HB 10 Basic) to getting thick extract. Extract concentration for assay is $10 \%, 20 \%$ and $30 \%$ in Na-CMC suspension ${ }^{9}$.

\section{Preparation and Grouping Animal Test ${ }^{9,10}$}

Animals model were purchase from pharmacology laboratory Faculty of Pharmacy UMI. It fasted about 18 hours, but drinking still receive. Animals were randomly divided into five groups and each group of three animal models. Group I is a control, group II, III, IV as a test group and group V as a positive controls.

\section{Testing of EEBL to Animals Models 9,10}

Animals models were administering on orally. At time $\mathrm{t}=0$, group I was given Na-CMC, Groups II, III and IV were each received EEBL a concentration of $10 \%, 20 \%$ and $30 \%$, group $\mathrm{V}$ was given Loperamide- $\mathrm{HCl}$ suspension, respectively by volume $1.0 \mathrm{ml} / 100 \mathrm{gbw}, 1 \mathrm{~h}$ before administration of castor oil. At time $\mathrm{t}=45 \mathrm{~min}$ after administration of castor oil, all groups were given marker charcoal suspension $0.1 \mathrm{~mL} / 100 \mathrm{~g}$ bw. At time $\mathrm{t}=65 \mathrm{~min}$, all groups were sacrificed by dislocation of cervical. Intestine removed then measured the total length of the intestine and creep distance marker charcoal. Then, calculated the ratio of the distance normal to the length of the colon charcoal marker entirely from pylorus to caecum ${ }^{10}$.

\section{Statistical Analysis}

Statistical analisys was used one way anova (ANOVA). The results of Analisys of Variant obtained from experiment groups $(p=0.05)$ and multiple comparisons of groups which cause different were calculated according to least significant different (LSD) $(\mathrm{p}=0,05)$ as post hock test ${ }^{9}$. 
Table 1. Ratio of marker charcoal

\begin{tabular}{|c|c|c|c|}
\hline No & Treatment & Ratio & Percent Inhibition \% \\
\hline 1 & Na-CMC & 0.671 & 0.00 \\
\hline 2 & EEBL $10 \%$ & 0.252 & 62.44 \\
\hline 3 & EEBL $20 \%$ & 0.142 & 78.84 \\
\hline 4 & EEBL $30 \%$ & 0.080 & 88.08 \\
\hline 5 & Loperamid-HCl & 0.069 & 89.72 \\
\hline
\end{tabular}

$\mathrm{EEBL}=$ Ethanolic extract of Bay Leaves

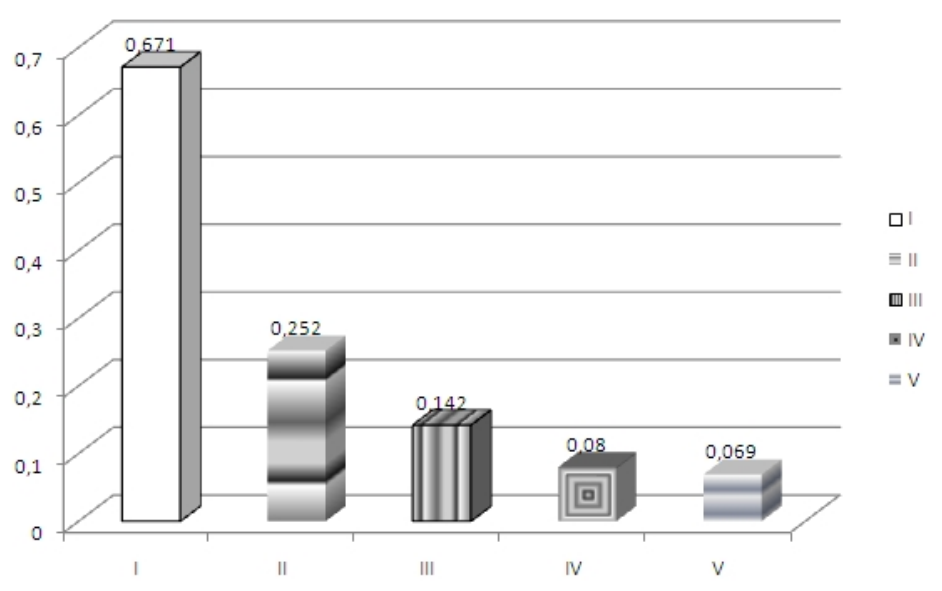

Figure 1. Rasio of flow carchoal marker in each groups Na-CMC, EEBL dan loperamid-HCl

\section{RESULTS}

In each group of mice, ratio of charcoal is measured with metric tools. Charcoal as marker indicated with black colours and then flow of line up charcoal equal entire size of colon from phundus to phylorus (Table 1). Value of Ration are shown that all group extract different compared to control Na-CMC (Fig.1).

\section{DISCUSSION}

Bay leaves (S. polyanthum [Wight.] Walp.) is a herbal widespred in Southeast Asia such as Indonesia country. It is used to flavoring agent and a native herbal medicine in Indonesia people to treat cholesterol, diarrhea, reduce of serum glucosa, LDL, and increase of $\mathrm{HDL}^{11,6}$ antibacteria, antifungi, and inducing apoptosis ${ }^{9}$, rheumatic, gastritis and hypertension, antioxidant activity ${ }^{12,13}$.

In case diarrhea is same characterized by secretory cause of hypermotility. The use of castor oil induced diarrhea is logical because it is cause to increase of intestinals peristaltic. Castor oil is hydrolized by lipase enzyme to glycerol and ricinoleat acid. Ricinoleat acid is cause of diarrhea.

Antidiarrhea is measured with transit intestinal method. Transit intestinal method used marker charcoal as indicator ${ }^{14}$ whereas flow of marker into overal intestinal from phundus to phylorus as determined. The delay of intestinal transit has been used to investigated bioactivity and effect as antidiarrhea no particular etiologic agen $\mathrm{t}^{15}$.

The result showing that control of $\mathrm{Na}-\mathrm{CMC}$ have hight ratio 0.671 . EEBL $10 \% ; 20 \% ; 30 \%$ is $0.252,0.142,0.080$, respectively and loperamide- $\mathrm{HCl} 0.069$ (Table 1). Percent inhibition diarrhea of animal model induced carcoal oil measured to control of NaCMC. Percent inhibition of EEBL $10 \%, 20 \%, 30 \%$ and loperamide- $\mathrm{HCl}$ is $63 \%, 78 \%, 88 \%$, and $89 \%$ respectively. Statistic analisys of ratio to all animals with ANOVA showing that significant different confidens level $95 \%$. Analisys of multiple comparison according post hoc tests with LSD showing that all extract is significant to compare with Na-CMC. At $10 \%$ and $20 \%$ is non significant, $10 \%, 30 \%$ and Loperamide- $\mathrm{HCl}$ is significant, and between $20 \%, 30 \%$ and Loperamide- $\mathrm{HCl}$ is non significant.

BL extract contains of phenolic, polyphenol e.g. tannin and flavonoid $^{12,14,2}$, 10-epigazanioplide, gazaniolid, spirafolide, costunolid, reinosin, santamarin ${ }^{8}$, volatile compounds e.g. citral $^{16,17}$. Bay leaves have active to Streptococcus $\mathrm{sp}^{6}$, S. enterica dan E.coli ${ }^{1,18}$. The extract activity of bay leaves may be related to the phenolic compounds present in the extracts. The phenolic such as tannin is potent as antidiarhea actifity.

The conclusion that EEBL have effect to diarrhea. This study can be supporting to develop of phytopharmaca. According to Ministry of health in Indonesia country, Bay leaves is one of the several herb to must be depelop as phytopharmaca.

\section{CONCLUSION}

Bay leaves extract in $30 \%$ have best antidiarrhea activity to animal models.

\section{ACKNOWLEDGMENT}

We would want to acknowledgment to the Ministry of Education and Cultural of Indonesia for financial support to our project in young lecturer research (Project number 0152/023-04.2/XXII/2010).

\section{REFERENCES}

1. Gupta YK, Gupta M, Aneja S, Kohli K. Current Drug Therapy of Protozoal Diarrhea. Indian Journal of Pediatrics 2004. Volume 71,55. http://dx.doi.org/10.1007/BF02725657

2. Wong SP, Leong LP, Koh JHW, Antioxidant activities of aqueous extracts of selected plants. J.Food Chem 2005. 07.058.

3. Winarno MW dan Sundari D, Pemanfatan Tumbuhan sebagai Obat Diare di Indonesia. Cermin Dunia Kedokteran 1996. No. 109, 25.

4. Adnyana IK, Yulinah E, Sigit JI, Fisheri K., Insanu M, Efek Ekstrak Daun Jambu Biji Daging Buah Putih dan Jambu Biji Daging Buah Merah Sebagai Antidiare. Acta Pharmaceutica Indonesia 2004; Vol. XXIX, No.1. 19-27.

5. Palombo EA, Traditional Plants and Herbal Remedies Used in the Treatment of Diarrheal Disease: Mode of Action, Quality, Efficacy, and Safety Considerations. In Ahmad, I., Aqil, F. and Owais M. (eds). Modern Phytomedicine 2006. Wiley-vch, Weinheim. http://dx.doi.org/ 10.1002/9783527609987.ch12 
6. Sumono A and Wulan A, Kemampuan air rebusan daun salam (Eugenia polyantha W) dalam menurunkan jumlah koloni bakteri Streptococcus sp. Majalah Farmasi Indonesia 2009. 20(3), 112-117.

7. Ditjen POM. Materi Medika Indonesia. Departemen Kesehatan Republik Indonesia. Jakarta. 1989; hal 67.

8. Fang F, Sang S, Chen KY, Gosslau A, Ho CT, Rosen RT, Isolation and identification of cytotoxic compounds from Bay leaf (Laurus nobilis). Food Chemistry 2005,93:497-501 http://dx.doi.org/10.1016 /j.foodchem.2004.10.029

9. Amin A, Malik A, Handayani V, Efek Antidiare Ekstrak Etanol Herba Permot (Passiflora Foetida L.). Fakultas Farmasi. UMI. Makassar; 2008.

10. Chitme HR, studies on anti-diarrheal activity of Calotropis gigantea R.BR. in experimental animals. J Pharm pharmaceut Sci 2004; 7(1) 7075 .

11. Aljamal A, Effects of Bay Leaves on Blood Glucose and Lipid Profiles on the Patients with Type 1 Diabetes. World Academy of Science, Engineering and Technology 2010; 45. 211-214.

12. Har LW and Ismail IS, Antioxidant activity, total phenolic and total flavonoid of Syzygium polyanthum (Wight) Walp leaves. Int. J. Med. Arom. Plants 2012, ISSN. 2249-4340.

13. Kaurinovic B, Popovic M, Vlaisavljevic S, In Vitro and in Vivo Effects of Laurus nobilis L. Leaf Extracts. Molecules 2010, 15, 3378-3390 http://dx.doi.org/10.3390/molecules15053378
14. Studiawan $\mathrm{H}$ dan Santosa MH, Uji Aktivitas Penurun Kadar Glukosa Darah Ekstrak Daun Eugenia polyantha pada Mencit yang Diinduksi Aloksan. Media Kedokteran Hewan 2005. Vol. 21, No. 2.

15. Ahmad I, Aqil F, Owais M, editors. Modern Phytomedicine Turning Medicinal Plants into Drugs. Wiley-Vch.Weinheim; 2006.

16. Devi SL, Kannappan S, and Anuradha CV, Evaluation in vitro antixidant activity of Indian bay leaf, Cinnamomum tamala (Buch.Ham.)T.Nes. \& Eberm using brain synaptosomes as model system. Indian Journal of Experimental Biology 2007; Vol. 45. pp. 778784.

17. Diäaz-Maroto MC, Rez-Coello SP and Cabezudo MD, Effect of Drying Method on the Volatiles in Bay Leaf (Laurus nobilis L.). 2002.

18. Chaudhry NMA and Tariq $P$, Bactericidal activity of black pepper, bay leaf, Aniseed and coriander against oral isolates. Pak. J. Pharm. Sci. 2006; Vol.19(3), 214-218.

Cite this article as:

Abd. Malik, Aktsar Roskiana Ahmad. Antidiarrheal activity of Etanolik extract of Bay leaves (Syzygium polyanthum [Wight.] Walp.). Int. Res. J. Pharm. 2013; 4(4):106-108 